\title{
Critical Issues of Chemical Kinetics in MILD Combustion
}

\author{
Pino Sabia* and Mara de Joannon \\ Istituto di Ricerche Sulla Combustione, Consiglio Nazionale delle Ricerche, Naples, Italy
}

Mild combustion processes occur with mixtures highly diluted and preheated by a strong recirculation of hot exhausted gases (thus mass and sensible enthalpy) within the combustion chamber. This strategy configures a process based on autoignition kernels outside or close to flammability limits transported by convection in the combustion chamber, thus defining a process with unique physical and chemical features drastically different from traditional deflagrative-diffusive flames. The article aims at analyzing the recent issues relative to kinetic aspects involved in moderate or intense low-oxygen dilution (MILD) combustion processes. First, the article comes through the identification of peculiar experimental features of simple hydrocarbons oxidation process induced by highly preheated and diluted conditions in model reactors typical of chemical engineering. Second, the effects of steam and carbon dioxides on fuel oxidation process, whose presence within the combustion chamber is imposed by high levels of hot gas

OPEN ACCESS

Edited by:

Nesrin Ozalp,

University of Minnesota Duluth,

United States

Reviewed by:

Tanvir I. Farouk,

University of South Carolina,

United States

Shiyou Yang,

Ford Motor Company, United States

*Correspondence:

Pino Sabia

sabia@irc.cnr.it

Specialty section: This article was submitted to

Thermal and Mass Transport,

a section of the journal

Frontiers in Mechanical Engineering

Received: 18 October 2019

Accepted: 28 January 2020

Published: 06 March 2020

Citation:

Sabia P and de Joannon M (2020) Critical Issues of Chemical Kinetics in MILD Combustion.

Front. Mech. Eng. 6:7.

doi: 10.3389/fmech.2020.00007 recirculation, are addressed. Third, the article comes through a thorough analysis of recent scientific contributions on kinetic aspects of MILD combustion processes to identify the critical points in modeling activities.

Keywords: jet stirred flow reactor, tubular flow reactor, combustion regimes, temperature oscillations, NTC behavior, $\mathrm{H}_{2} \mathrm{O}$ and $\mathrm{CO}_{2}$ chemical effects, chemistry modeling queries

\section{INTRODUCTION}

The attention of the scientific and industrial community involved in the identification and development of energy production systems has been devoted to new technologies under the keywords of high efficiency and reduced emissions. Given this background, clean combustion processes still can play an important role, but they are required to be flexible with respect to thermal loads, to respond to the fluctuation of energy produced (Luo et al., 2015) by renewable sources in virtue of their intrinsic intermittence (Lund and Kempton, 2008; Keyhani et al., 2010; Østergaard, 2012; Abdmouleh et al., 2015) and to be flexible with respect to fuel nature itself, given the high variability of fuels composition and smart "energy carriers" (Spliethoff et al., 1996; McKendry, 2002; Demirbas, 2004; Hosseini and Wahid, 2016; Van Vuuren et al., 2017; SMARTCATs COST ${ }^{1}$ ). Such a further requirement embitters the difficulties to develop advanced combustion technologies, because new processes [i.e., staged combustion, lean premixed, etc. (Zabetta et al., 2005; Huang and Yang, 2009; Dunn-Rankin, 2011; Cozzi and Coghe, 2012)] may work properly in restricted ranges of system parameters.

Among new combustion concepts, one promising candidate to simultaneously meet thermal efficiency needs and pollutant emission restrictions, while responding to fuel and thermal load flexibility, appears to be the moderate or intense low-oxygen dilution (MILD) combustion

\footnotetext{
${ }^{1}$ SMARTCATs COST Action CM1404, http://www.smartcats.eu/.
} 
(Wünning and Wünning, 1977; Weber et al., 2000, 2005; Cavaliere and de Joannon, 2004; Dally et al., 2004; Milani and Wünning, 2007). This combustion is also renewed as flameless oxidation (or FLOX) (Wünning and Wünning, 1977; Milani and Wünning, 2007), high-temperature air combustion (Katsuki and Hasegawa, 1998; Tsuji et al., 2003), and low-temperature combustion for engine applications (Saxena and Bedoya, 2013).

The MILD combustion has been successfully employed in furnaces and boilers, and it could be potentially used into many other applications, such as gas turbines, biogas burners, burners for hydrogen reformers, or for combined heat and power (CHP) units and engines (Levy et al., 2004; Riccius et al., 2005; Lückerath et al., 2008; Khalil and Gupta, 2011; Li et al., 2011; Reddy et al., 2015; Ho et al., 2016). In addition, MILD-oxyfuel combustion for coal combustions represents a subcategory of MILD processes with high potentiality to overcome problems relative to oxycombustion systems (Li et al., 2011, 2013).

MILD combustion relies on a strong recirculation of mass and sensible enthalpy by recycling the exhausted gases to dilute and simultaneously preheat fresh reactants (Wünning and Wünning, 1977; Katsuki and Hasegawa, 1998; Weber et al., 2000, 2005; Tsuji et al., 2003; Cavaliere and de Joannon, 2004; Dally et al., 2004; Milani and Wünning, 2007; Khalil and Gupta, 2011; Saxena and Bedoya, 2013; Reddy et al., 2015). The intrinsic nature of the process is based on autoignition/fuel-ultra-lean kernels that increase in size while being transported by convection (Van Oijen, 2013; Minamoto and Swaminathan, 2015), imposed by high-turbulence exhausted gas recirculation fluid-dynamics patterns, thus defining a process with homogenous intensive parameters within the combustion chamber (Özdemir and Peters, 2001; Noor et al., 2013a; Sidey et al., 2014; Sidey and Mastorakos, 2015).

Characteristic working temperatures are modest $(T<$ $1,500 \mathrm{~K}$ ) and below critical values for the production of pollutants (i.e., $\mathrm{NO}_{\mathrm{x}}$, particulate matter; Wünning and Wünning, 1977; Weber et al., 2000; Cavaliere and de Joannon, 2004; Milani and Wünning, 2007), while complete fuel conversion, high thermal efficiencies, and process stability are ensured by the high recirculated sensible enthalpy. Because the stability of the oxidation process does not rely on heat feedback mechanisms from the flame front, as in conventional diffusion/deflagrative flames, but on the recycled sensible heat, the process is intrinsically highly flexible with respect to fuels chemical/physical properties and quality (Weber et al., 2005; Colorado et al., 2010; Derudi and Rota, 2011; Hosseini and Wahid, 2013; Noor et al., 2013a), given that the mixture temperature after the mixing process between fresh reactants and recirculated gas is higher than mixtures autoignition one.

MILD combustion processes present unique physical/chemical features, drastically different from traditional combustion systems, which should be discussed at basic levels for the fine comprehension of the process itself. The structure of the reactive region (Özdemir and Peters, 2001; de Joannon et al., 2012a,b; Van Oijen, 2013; Minamoto et al., 2014; Minamoto and Swaminathan, 2015; Sorrentino et al., 2019), the chemistry (de Joannon et al., 2005; Zhukov et al., 2005; Li et al., 2014; Sabia et al., 2014; Lubrano Lavadera et al., 2018b), and the interaction between chemistry-turbulence (Dally et al., 2004; Parente et al., 2008, 2016; Isaac et al., 2013; Noor et al., 2013b) represent key points to address, with strong implications also on modeling activities (Dally et al., 2004; Parente et al., 2008, 2016; Isaac et al., 2013; Noor et al., 2013b).

Among the issues to consider, the chemical aspect of the oxidation process represents a fundamental one. In fact, the high levels of dilution coupled with moderate working temperatures imply a drastic change of the kinetics involved during the fuel oxidation process with respect to flame chemistry, with relatively lower chemical characteristic times and heat release rates (Dally et al., 2004; de Joannon et al., 2005; Zhukov et al., 2005; Parente et al., 2008, 2016; Isaac et al., 2013; Noor et al., 2013b; Li et al., 2014; Sabia et al., 2014; Lubrano Lavadera et al., 2018b). Furthermore, it occurs in presence of great amounts of non-inert species, such as carbon dioxide and steam, which can alter the kinetic routes by means of several effects, here reported:

1) Thermal: higher heat capacities with respect to $N_{2}$, thus lower adiabatic flame temperature;

2) Kinetic: they participate directly in bimolecular reactions and enhance the role of third-molecular reactions because of higher third-body efficiencies with respect to $\mathrm{N}_{2}$. For these effects, a huge literature has been produced in the last decade, as reported in the next paragraphs (Fedyaeva et al., 2018; Lubrano Lavadera et al., 2018a).

In addition, these species can modify the structure of the reactive region because of the variation of the transport properties of the mixture (Dally et al., 2004; Mardani et al., 2010, 2013) and lowering local temperatures by enhancing heat radiation transfer (Dally et al., 2004; Mardani et al., 2013; Sorrentino et al., 2018; Zhang et al., 2019) mechanisms, because of their high radiative properties.

In this article, the chemical issues of MILD combustion processes are discussed. They will be analyzed throughout the implication on simple hydrocarbons oxidation chemistry, but the discussion could be extended to higher pressures (Gurentsov et al., 2002; Zhukov et al., 2005; Sjöberg et al., 2007; Le Cong and Dagaut, 2008, 2009a,b; Anderlohr et al., 2010; Xie et al., 2014b; Donohoe et al., 2015), to $\mathrm{H}_{2}$ and syngas (Mueller et al., 1999; Park et al., 2003; Wang et al., 2003; Zabetta et al., 2005; Le Cong and Dagaut, 2008; Lee et al., 2012; Xie et al., 2014a), or to highmolecular-weight paraffins at elevated pressures (Sjöberg et al., 2007; Anderlohr et al., 2010).

\section{OXIDATION PROCESS OF SIMPLE HYDROCARBONS UNDER DILUTED CONDITION}

MILD oxidation configures as a chemically controlled process with characteristic kinetic times relatively longer than the ones involved in traditional flames. Within this slow oxidation regime, system exchange phenomena can drastically endorse the establishment of instabilities if coupled with complex heat reaction release rates, given the high non-linearity of exothermic/endothermic reactions. The direct experimental 
evidence is the insurgence of peculiar oxidation phenomena, as reported in the following.

Figure 1 is relative to the experimental combustion regimes detected for methane/oxygen mixtures diluted in nitrogen at $d=$ $90 \%$ at environmental pressure in a jet stirred flow reactor (JSFR) (de Joannon et al., 2005) and in a tubular flow reactor (TFR) (Sabia et al., 2014).

Figures 1A,B are relative to the JSFR. The mixture averaged residence time $(\tau)$ is $0.5 \mathrm{~s}$. The characteristic combustion regimes were summarized in a carbon/oxygen feed ratio/mixture inlet temperature $\left(\mathrm{C} / \mathrm{O}-T_{\text {in }}\right)$ map. Steady combustion and dynamic behaviors were identified. The widest region corresponds to steady stationary combustion conditions. For $\mathrm{C} / \mathrm{O}<0.55$ and for
$1,150<T_{\text {in }}<1,200 \mathrm{~K}$, the system shows more complex behaviors with the establishment of temperature oscillations in time. As it can be seen from Figure 1A, this area is divided into several zones on the basis of different temperature waveforms (Figure 1B). This range of behavior reflects the richness of oxidation kinetics promoted under MILD conditions.

Numerical investigations devoted to the delineation of the controlling kinetics of these phenomenologies revealed that methane oxidation at low temperatures $(<1,000 \mathrm{~K})$ is sustained by this set of reactions $\mathrm{H}+\mathrm{O}_{2}+\mathrm{M}=\mathrm{HO}_{2}+\mathrm{M}, \mathrm{HO}_{2}+$ $\mathrm{HO}_{2}=\mathrm{H}_{2} \mathrm{O}_{2}+\mathrm{O}_{2}$, and $\mathrm{H}_{2} \mathrm{O}_{2}+\mathrm{M}=\mathrm{OH}+\mathrm{OH}+\mathrm{M}$ coupled with $\mathrm{HCO}+\mathrm{O}_{2}=\mathrm{CO}+\mathrm{HO}_{2}$ for $\mathrm{HO}_{2}$ production, whereas methane converts to $\mathrm{CO}$ through the following chemical
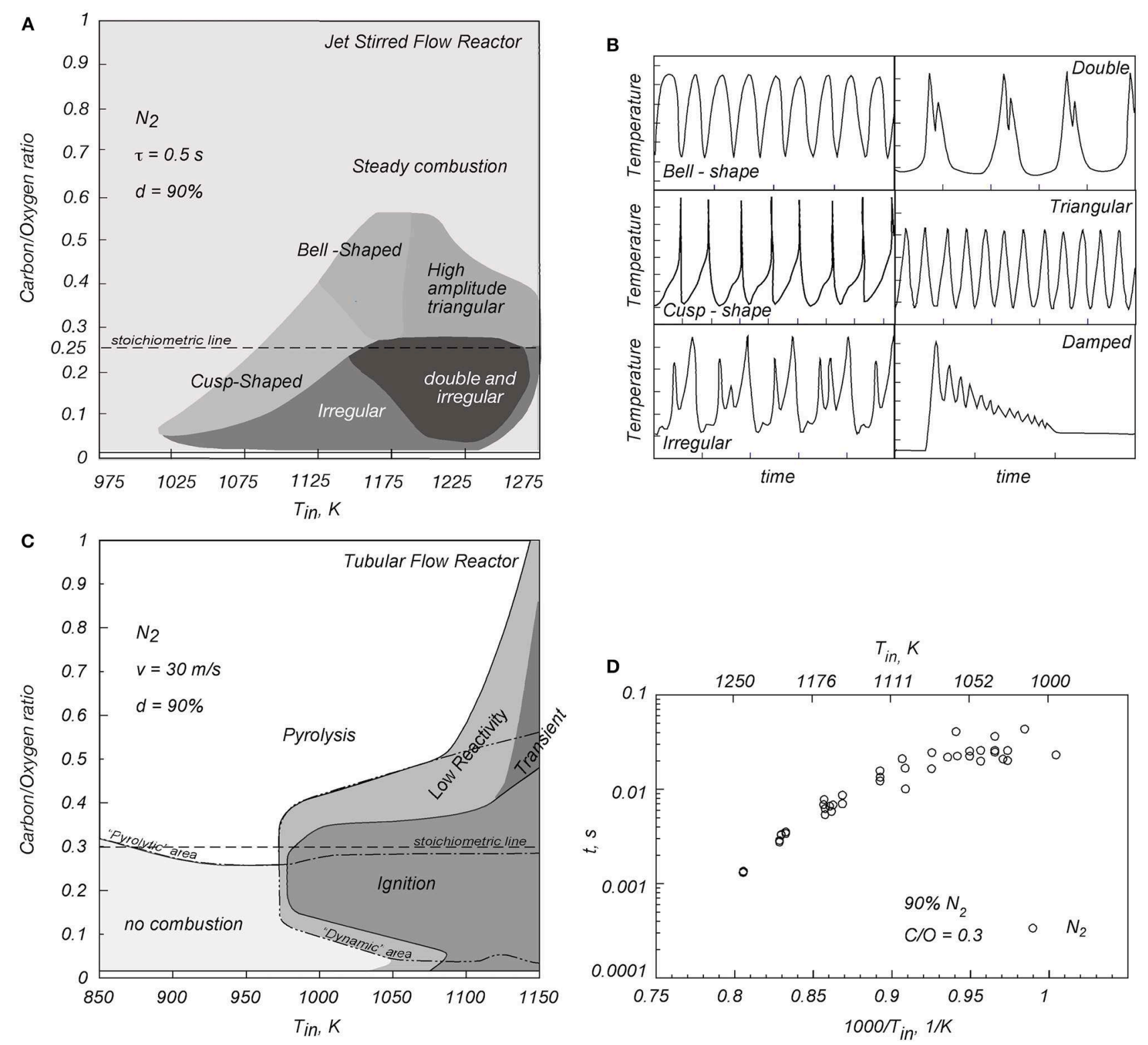

FIGURE 1 | (A,B) Dynamic behaviors and temperature oscillation shapes for a methane/oxygen mixture in a JSFR, from de Joannon et al. (2005). (C,D) Combustion regimes, and NTC-like behavior of autoignition delay times for propane/oxygen mixtures in a TFR, from Sabia et al. (2014). 
route $\mathrm{CH}_{3}+\mathrm{HO}_{2} \rightarrow \mathrm{CH}_{3} \mathrm{O} \rightarrow \mathrm{CH}_{2} \mathrm{O} \rightarrow \mathrm{HCO} \rightarrow \mathrm{CO}$ ) (de Joannon et al., 2005; Glarborg and Bentzen, 2007; Le Cong and Dagaut, 2008, 2009a,b; Mendiara and Glarborg, 2009; Wang et al., 2013; Sabia et al., 2014, 2015; Xie et al., 2014a; Song et al., 2015; Lubrano Lavadera et al., 2016, 2018a). For the conditions where temperature oscillations were detected, methyl radicals are directly oxidized to $\mathrm{CH}_{2} \mathrm{O}\left(\mathrm{CH}_{3}+\mathrm{OH} \rightarrow \mathrm{CH}_{2} \mathrm{O}+\mathrm{H}_{2}\right)$ by $\mathrm{OH}$ radicals produced by the high-temperature branching mechanism of the subsystem $\mathrm{H}_{2} / \mathrm{O}_{2}$. At the same time, methyl radicals recombine to ethane $\left(\mathrm{CH}_{3}+\mathrm{CH}_{3}+\mathrm{M}=\mathrm{C}_{2} \mathrm{H}_{6}\right.$ $+\mathrm{M}$ ), followed by $\mathrm{C}_{2}$ dehydrogenation/pyrolytic routes. The competition between oxidation/recombination-pyrolytic routes, coupled with system heat exchange phenomena, promotes instabilities (de Joannon et al., 2005; Sabia et al., 2014; Lubrano Lavadera et al., 2018b). The enhanced role of the methyl recombination routes for these temperatures is emphasized also in other works (Zhukov et al., 2005; Li et al., 2014).

For higher $T_{\text {in }}(>1,250 \mathrm{~K})$, the activation of further oxidative routes $\left(\mathrm{CH}_{3}+\mathrm{OH}+\mathrm{M} \rightarrow \mathrm{CH}_{3} \mathrm{OH} \rightarrow \mathrm{CH}_{2} \mathrm{OH} \rightarrow \mathrm{CH}_{2} \mathrm{O}\right)$ followed by $\mathrm{CH}_{2} \mathrm{O} \rightarrow \mathrm{HCO} \rightarrow \mathrm{CO} \rightarrow \mathrm{CO}_{2}$, or $\mathrm{CH}_{3}+$ $\mathrm{OH} \rightarrow \mathrm{CH}_{2}(\mathrm{~s}) \rightarrow \mathrm{CH}_{2} \rightarrow \mathrm{CH} \rightarrow \mathrm{CO}$, relieves the system from the inhibiting effect of methyl radicals conversion to ethane; thus, the system reaches a steady stationary state (Lubrano Lavadera et al., 2018b).

Figures 1C,D are relative to experimental tests in a TFR (Sabia et al., 2014). It is equipped with thermocouples equidisplaced along the axial coordinate of the system, to detect ignition/oxidation states. Following the same methodology used for the JSFR data, the characteristic combustion regimes were summarized in a $\mathrm{C} / \mathrm{O}-T_{\text {in }}$ map.

For low $T_{\text {in }}(850-975 \mathrm{~K})$, no combustion was detected for $\mathrm{C} / \mathrm{O}$ $<0.3$ (stoichiometric condition), whereas for rich mixtures, a pyrolytic behavior was identified (temperature values lower than the isothermal inlet profiles). As $T_{\text {in }}$ is increased, for $\mathrm{C} / \mathrm{O}=0.3$, the operative conditions lead to ignition, defined as a temperature increase of $10 \mathrm{~K}$ (Mardani et al., 2010, 2013) with respect to the inlet axial one $\left(T_{\text {in }}\right)$. When $T_{\text {in }}$ is increased up to $1,080 \mathrm{~K}$, the ignition region extends to fuel leaner conditions, while remaining almost constant for the fuel-rich side. For $T_{\text {in }}>1,120 \mathrm{~K}$, the ignition region extends up to $\mathrm{C} / \mathrm{O}=0.5$. Between the ignition and the pyrolysis-no combustion regions, a low reactivity behavior occurs with a temperature increase lower than $10 \mathrm{~K}$ with respect to $T_{\text {in }}$, thus not satisfying the ignition criterion (de Joannon et al., 2002; Evans et al., 2017).

Conditions included within the dynamic line show oscillatory behaviors, for which two temperature profiles are recorded, downstream of a steady ignition point, periodically switching from one to the other in time. The last region, indicated as transient (enclosed by the dotted line), identifies conditions where mixtures temporarily ignite, leading to a temporarily first steady state, followed by a second final one.

Figure 1D reports the autoignition delay times $(t)$ with respect to mixture inlet temperature $\left(T_{\text {in }}\right)$ for the stoichiometric condition in the Arrhenius plot diagram. The autoignition delay time is defined as the ratio between the axial positions where the temperature increase is equal to $10 \mathrm{~K}$ and the flow mean velocity (Sabia et al., 2014). The autoignition delay time curve shows two different slopes with respect to $T_{\text {in }}$ : for
$T_{\text {in }}$ lower than about $1,100 \mathrm{~K}, t$ is almost independent from $T_{\text {in }}$, whereas for $1,000 / T_{\text {in }}<0.9, t$ linearly diminishes with temperature. Such a trend was identified for $0.15<\mathrm{C} / \mathrm{O}<0.3$. Congruently with the methane dynamic behavior in the JSFR, the negative temperature coefficient (NTC)-like phenomenology and the oscillatory regimes detected in the TFR emerge from the competing methyl radicals oxidative/recombination-pyrolytic routes at intermediate temperatures $(1,000<T<1,100 \mathrm{~K})$, whereas the $\mathrm{H}_{2} / \mathrm{O}_{2}$ system is passing from the low- to the hightemperature branching mechanism.

In similar operative conditions, NTC-like and oscillatory behaviors were detected in other systems for simple hydrocarbons (Cadman et al., 2000; Penyazkov et al., 2005; Zhukov et al., 2005; Gallagher et al., 2008; Sabia et al., 2013; Lubrano Lavadera et al., 2016, 2018a; Hashemi et al., 2017).

As evident, the nature of such behaviors is very different from conventional "cool" flame or "NTC" phenomena observed for low-molecular-weight paraffins at high pressures (Herzler et al., 2004; Gallagher et al., 2008; Hashemi et al., 2016, 2017, 2019) or high-molecular-weight paraffins (Sokolov et al., 1996; Basevich and Frolov, 2007; Ju et al., 2019; Wang et al., 2019), where the oxidation chemistry of alkyl-peroxide radicals is fundamental. In particular, for high-molecular-weight paraffins, a double $\mathrm{O}_{2}$ addition to alkyl-radicals and internal isomerization to ketohydroperoxy radicals, ruled by equilibrium reactions, determine temperature oscillations in time or the NTC behavior (if referred to ignition delay times), coupled with heat exchange mechanisms.

\section{OXIDATION PROCESS OF SIMPLE HYDROCARBONS UNDER DILUTED CONDITION IN PRESENCE OF $\mathrm{H}_{2} \mathrm{O}$ AND $\mathrm{CO}_{2}$}

As examples of the chemical effects of $\mathrm{H}_{2} \mathrm{O}$ and $\mathrm{CO}_{2}$ on combustion processes, Figure 2 reports some recent experimental data, adapted from Sabia et al. (2015), Lubrano Lavadera et al. (2016, 2018a). In Figure 2, round symbols are relative to the $\mathrm{N}_{2}$ - diluted mixtures, triangles to the $\mathrm{CO}_{2}$-diluted mixtures, and squares to the $\mathrm{H}_{2} \mathrm{O}$-partially diluted one. Figure 2A shows the experimental $\Delta T=$ $\left(T_{\text {reactor }}-T_{\text {inlet }}\right)$ obtained for the stoichiometric condition obtained in a JSFR (de Joannon et al., 2005; Sabia et al., 2014) for these three cases. The residence time $(\tau)$ is equal to $0.5 \mathrm{~s}$, and the overall mixture dilution level $(d)$ is $90 \%$.

For the $\mathrm{N}_{2}$-diluted mixture, the oxidation onset occurs for $T_{\text {in }}$ $=880 \mathrm{~K}$. The system temperature increases monotonously up to $T_{\text {in }}=940 \mathrm{~K}$, and then the oxidation occurs throughout temperature oscillatory regimes, likewise the methane (Figures 1A,B). For this oxidation regime, the maximum and minimum values detected during the oscillatory behavior (full symbols) are reported. Afterward, for $T_{\text {in }}=1,100 \mathrm{~K}$, a stationary steady condition is identified.

The experimental $\Delta T$ for the $\mathrm{CO}_{2}$-diluted mixture and the system partially diluted in $\mathrm{H}_{2} \mathrm{O}\left(45 \% \mathrm{H}_{2} \mathrm{O}-55 \% \mathrm{~N}_{2}\right)$ are similar to the ones relative to the $\mathrm{N}_{2}$-diluted one. Nonetheless, the 

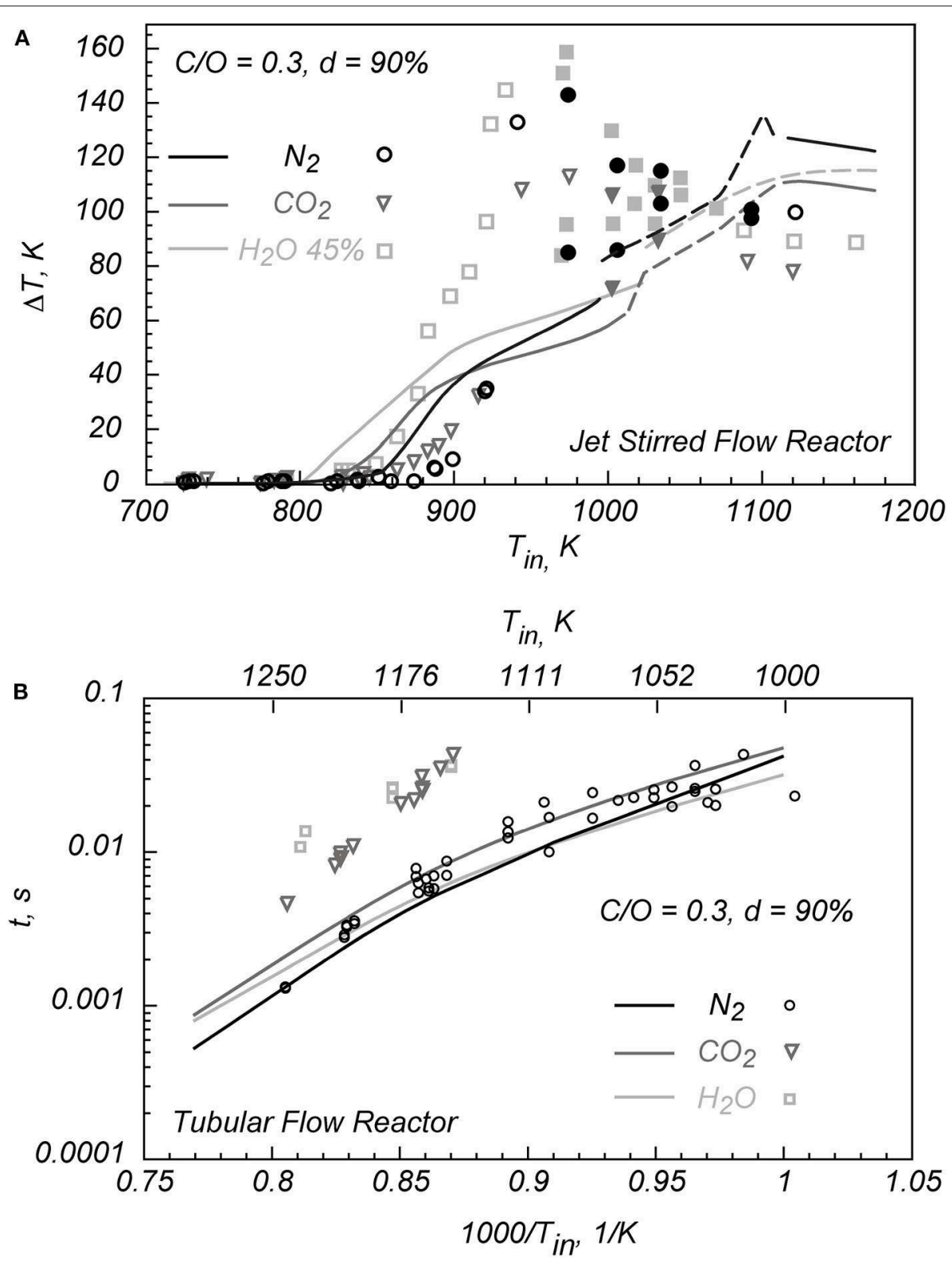

FIGURE 2 | Effects of $\mathrm{H}_{2} \mathrm{O}$ and $\mathrm{CO}_{2}$ on the oxidation process of stoichiometric $\mathrm{C}_{3} \mathrm{H}_{8} / \mathrm{O}_{2}$ mixtures in a JSFR (A), adapted from Lubrano Lavadera et al. (2018a) and Lubrano Lavadera et al. (2016), and the autoignition delay times of stoichiometric $\mathrm{C}_{3} \mathrm{H}_{8} / \mathrm{O}_{2}$ mixtures in a TFR (B), adapted from Sabia et al. (2015).

oxidation onset occurs, respectively, for $T_{\text {in }}=820 \mathrm{~K}$ and for $T_{\text {in }}$ $=850 \mathrm{~K}$, thus slightly anticipating the reactivity with respect to the reference system. For $\mathrm{CO}_{2}$, oscillation occurs for $1,030 \mathrm{~K}<$ $T_{\text {in }}<1,100 \mathrm{~K}$, whereas for the system diluted in $\mathrm{H}_{2} \mathrm{O}$ for $980 \mathrm{~K}$ $<T_{\text {in }}<1,100 \mathrm{~K}$. Afterward, a stationary steady state regime is detected for both the mixtures. At high temperatures, the system diluted in $\mathrm{N}_{2}$ shows a higher temperature increment.

Along with the experimental data, Figure 2A reports the numerical simulations obtained with a detailed kinetic model PoliMi (Cadman et al., 2000; Faravelli et al., 2003; Frassoldati et al., 2003), as reported in Lubrano Lavadera et al. (2018a) and Lubrano Lavadera et al. (2016). In general, it well-predicts both the anticipating effect of $\mathrm{CO}_{2}$ and $\mathrm{H}_{2} \mathrm{O}$ at low temperatures and the temperature oscillatory behaviors (dashed lines), even though overestimates system reactivities at low temperatures, considering $\Delta T$ as the reference parameter.

Figure 2B shows the experimental autoignition delay times $(t)$ for a stoichiometric propane/oxygen mixture diluted at $d=90 \%$ in $\mathrm{N}_{2}, \mathrm{CO}_{2}$, and $\mathrm{H}_{2} \mathrm{O}$ along with numerical predictions (lines) (Sabia et al., 2015).

For the system diluted in $\mathrm{CO}_{2}$ and $\mathrm{H}_{2} \mathrm{O}$, the experimental autoignition delay times $(t)$ are longer of almost one order of magnitude with respect to the ones obtained for the $\mathrm{N}_{2}$-diluted mixture. 
The autoignition delay times obtained for $\mathrm{N}_{2}$ are predicted with a good approximation, but this consistency fails for the other two diluents. Because MILD combustion configures as a continuous autoignition states, the fine comprehension of the chemical effect of $\mathrm{CO}_{2}$ and $\mathrm{H}_{2} \mathrm{O}$ is mandatory.

\section{DISCUSSION AND CONCLUSION}

There are different main aspects that should be considered in the development of detailed oxidation chemistry for MILD combustion processes.

The first point concerns the complexity of the oxidation process at low $(T<1,000 \mathrm{~K})$ to intermediate $(1,000 \mathrm{~K}<T<$ $1,200 \mathrm{~K})$ temperatures. In fact, under these operative conditions, the numbers of species and consequently of elementary reactions are meaningfully larger with respect to the ones necessary to describe the high-temperature flame oxidation processes. This implies high computational cost for computational fluid dynamics (CFD) calculations, because detailed chemistries are required. As previously shown, the light hydrocarbons chemistry under these operating conditions is governed by a delicate balance between slow oxidation and recombination/pyrolytic channels. Uncertainties of the Arrhenius parameters (Konnov, 2008; Varga et al., 2015) of elementary reactions and of thermodynamic data have a stronger impact on the predictive performance of kinetic models with respect to conventional flame conditions. In fact, at high temperatures, the performance of kinetic schemes relies on the proper description of the high-temperature branching reactions of the subsystem $\mathrm{H}_{2} / \mathrm{O}_{2}$. The fast chemistry promoted by such reactions may hide the elementary reaction constants uncertainties of slow reactions, reducing the impact of their relative weight in the prediction of combustion features.

The presence of $\mathrm{H}_{2} \mathrm{O}$ and $\mathrm{CO}_{2} a b$ initio poses several problems. First, their interaction on fuel oxidation kinetics process is an aspect not contemplated for traditional systems, where $\mathrm{H}_{2} \mathrm{O}$ and $\mathrm{CO}_{2}$ are present as combustion products in the postoxidation phase, thus acting only on a subset of kinetic reactions that involve few species close to equilibrium conditions. On the contrary, $\mathrm{CO}_{2}$ and $\mathrm{H}_{2} \mathrm{O}$ can drastically alter the ignition process in dependence of operating conditions with a twofold interaction. They increase system reactivity at low temperatures (Sabia et al., 2007, 2015; Sjöberg et al., 2007; Anderlohr et al., 2010; Lubrano Lavadera et al., 2016), but delay it at intermediatehigh temperatures (Mueller et al., 1999; Cadman et al., 2000; de Joannon et al., 2002; Park et al., 2003; Wang et al., 2003, 2013; Herzler et al., 2004; Penyazkov et al., 2005; Zabetta et al., 2005; Basevich and Frolov, 2007; Glarborg and Bentzen, 2007; Sjöberg et al., 2007; Gallagher et al., 2008; Le Cong and Dagaut, 2009a,b; Mendiara and Glarborg, 2009; Mardani et al., 2010, 2013; Lee et al., 2012; Sabia et al., 2013, 2015; Chen and Ghoniem, 2014; Xie et al., 2014a; Song et al., 2015; Zou et al., 2015; Hashemi et al., 2016, 2017, 2019; Lubrano Lavadera et al., 2016, 2018a; Evans et al., 2017; He et al., 2017; Fedyaeva et al., 2018; Sorrentino et al., 2018; Zhang et al., 2019).
These effects mainly depend on the interaction that such species have on the branching mechanisms, related to the $\mathrm{H}_{2} / \mathrm{O}_{2}$ subsystem. At low temperatures, the ignition-oxidation chemistry is sustained by hydrogen peroxides molecule formation and decomposition to $\mathrm{OH}$ radicals, namely, $\mathrm{H}+\mathrm{O}_{2}$ $+\mathrm{M}=\mathrm{HO}_{2}+\mathrm{M}, \mathrm{HO}_{2}+\mathrm{HO}_{2}=\mathrm{H}_{2} \mathrm{O}_{2}+\mathrm{O}_{2}$, and $\mathrm{H}_{2} \mathrm{O}_{2}+$ $\mathrm{M}=\mathrm{OH}+\mathrm{OH}+\mathrm{M}$. At intermediate-high temperatures, the branching mechanism relies on the following set of reaction $\mathrm{H}+$ $\mathrm{O}_{2}=\mathrm{OH}+\mathrm{O}, \mathrm{O}+\mathrm{H}_{2}=\mathrm{OH}+\mathrm{H}$, and $\mathrm{OH}+\mathrm{H}_{2}=\mathrm{H}_{2} \mathrm{O}+\mathrm{H}$.

Literature works, relative to $\mathrm{H}_{2} \mathrm{O}$ and $\mathrm{CO}_{2}$ effects on $\mathrm{H}_{2}$ oxidation (Mueller et al., 1999; Park et al., 2003; Wang et al., 2003; Lee et al., 2012; Xie et al., 2014b), suggest that they act on the lowtemperature mechanism due to their high third-body collisional efficiencies, enhancing the reaction $\mathrm{H}+\mathrm{O}_{2}+\mathrm{M}=\mathrm{HO}_{2}+\mathrm{M}$ to the detriment of $\mathrm{H}+\mathrm{O}_{2}=\mathrm{OH}+\mathrm{O}_{2}$ at low temperatures. At high temperatures, $\mathrm{H}_{2} \mathrm{O}$ delays reaction $\mathrm{H}_{2}+\mathrm{OH}=\mathrm{H}_{2} \mathrm{O}$ $+\mathrm{H}$, by shifting its equilibrium state, and $\mathrm{O}+\mathrm{H}_{2}=\mathrm{OH}+$ $\mathrm{H}$ as $\mathrm{O}$ radicals is consumed by reaction $\mathrm{O}+\mathrm{H}_{2} \mathrm{O}=\mathrm{OH}+$ $\mathrm{OH}$. In general, $\mathrm{H}_{2} \mathrm{O}$ leads to a change of radicals distribution, decreasing $\mathrm{H}$ and $\mathrm{O}$ while promoting $\mathrm{OH}$ concentration. At high temperatures, $\mathrm{CO}_{2}$ further inhibits reaction $\mathrm{H}+\mathrm{O}_{2}=\mathrm{OH}+$ $\mathrm{O}$ by consuming $\mathrm{H}$ radicals throughout decomposition reactions $\left(\mathrm{CO}_{2}+\mathrm{H}=\mathrm{CO}+\mathrm{OH}\right)$ (Glarborg and Bentzen, 2007; Le Cong and Dagaut, 2008, 2009a,b; Mendiara and Glarborg, 2009; Song et al., 2015).

Fuel oxidation chemistry in presence of $\mathrm{H}_{2} \mathrm{O}$ and $\mathrm{CO}_{2}$ is further complicated by their possibility to interact with the $\mathrm{C}_{1}$ $\mathrm{C}_{2}$ reactions directly in bimolecular reactions or indirectly as third-body species in third-molecular reactions.

Such species can sensibly alter the intermediate temperature consumption of $\mathrm{CH}_{3}$ rates by promoting methyl recombination routes to $\mathrm{C}_{2}$ species, as high collisional efficiency third-body species. Steam can partially reconvert methyl radicals back to methane $\left(\mathrm{CH}_{3}+\mathrm{H}_{2} \mathrm{O}=\mathrm{CH}_{4}+\mathrm{OH}\right)$, thus inhibiting system reactivity (Sabia et al., 2015). At the same time, $\mathrm{CO}_{2}$ can strongly interact in the $\mathrm{C}_{1}$ high-temperature chemistry through the reaction $\mathrm{CH}_{2}(\mathrm{~S}) / \mathrm{CH}_{2}+\mathrm{CO}_{2}=\mathrm{CH}_{2} \mathrm{O}+\mathrm{CO}$ (Glarborg and Bentzen, 2007; Le Cong and Dagaut, 2009a,b; Mendiara and Glarborg, 2009; Sabia et al., 2015; He et al., 2017). Recently, He et al. (He et al., 2017) have introduced a new methyl radical conversion channel $\left(\mathrm{CH}_{3} \rightarrow \mathrm{CH}_{3} \mathrm{OCO} \rightarrow \mathrm{CH}_{2} \mathrm{O}\right.$ and $\mathrm{CH}_{3} \rightarrow$ $\mathrm{CH}_{3} \mathrm{OCO} \rightarrow \mathrm{CO}$ ) exclusive in $\mathrm{O}_{2} / \mathrm{CO}_{2}$ atmospheres for methane oxidation chemistry at high temperatures.

As it has emerged within this brief description, kinetic mechanisms involve a set of third-molecular reactions whose role is emphasized by third-molecular species with high collisional efficiencies (such $\mathrm{CO}_{2}$ and $\mathrm{H}_{2} \mathrm{O}$ ). In this context, the reaction $\mathrm{H}+\mathrm{O}_{2}+\mathrm{M}=\mathrm{HO}_{2}+\mathrm{M}$ plays a crucial role for $\mathrm{HO}_{2}$ radical production. In this regard, it is worth mentioning that big uncertainties on kinetic parameters still remain (Konnov, 2008; Varga et al., 2015). All these works highlight that for such a reaction there are considerable scattered data especially for the low-pressure limit with big uncertainties for thirdbodies collisional efficiencies. Some recent efforts to calculate these values were made by Jasper et al. (2015) for monoatomic and biatomic species, whereas Shao et al. (2019) have recently proposed new values for $\mathrm{H}_{2} \mathrm{O}$ and $\mathrm{CO}_{2}$. 
The problem relative to third-body collisional efficiency uncertainties is even more relevant if it is considered that they may exhibit temperature dependence. For instance, Baulch et al. (1988) suggested a temperature dependence $\mathrm{k}\left(\mathrm{H}_{2} \mathrm{O}\right) / \mathrm{k}\left(\mathrm{N}_{2}\right)=$ $1.36 \mathrm{~T}^{0.4}$ for water in the reaction $\mathrm{H}+\mathrm{O}_{2}+\mathrm{M}=\mathrm{HO}_{2}+\mathrm{M}$, whereas Davis et al. (2005) suggested a temperature dependence $\mathrm{k}\left(\mathrm{H}_{2} \mathrm{O}\right) / \mathrm{k}\left(\mathrm{MN}_{2}\right)=60 \mathrm{~T}^{0.25}$ for water in the elementary reaction $\mathrm{H}+\mathrm{H}+\mathrm{M}=\mathrm{H}_{2}+\mathrm{M}$. Also, for the reaction $\mathrm{CH}_{4}+\mathrm{H}=\mathrm{CH}_{3}$ $+\mathrm{H}_{2}$, Jasper et al. (2013) suggested $\left(\mathrm{H}_{2} \mathrm{O}\right) / \mathrm{k}\left(\mathrm{Ar}_{\mathrm{r}}\right)$ should be 3 at $300 \mathrm{~K}$ and 7 at $2,000 \mathrm{~K}$.

The definition itself of third-body species with thirdmolecular efficiencies different from 1 is ambiguous. Several authors have proposed third-body collisional efficiencies also for $\mathrm{H}_{2} \mathrm{O}_{2}$ and $\mathrm{HO}_{2}$, with collisional efficiencies similar to the ones declared for steam (Gerasimov and Shatalov, 2013).

In addition, the basic chemistry of the $\mathrm{H}_{2} / \mathrm{O}_{2}$ mechanism would require a right description of $\mathrm{H}+\mathrm{HO}_{2}$ reactions (i.e., $\mathrm{H}+\mathrm{HO}_{2}=\mathrm{OH}+\mathrm{OH}, \mathrm{H}+\mathrm{HO}_{2}=\mathrm{H}_{2}+\mathrm{O}_{2}$, and $\mathrm{HO}_{2}+$ $\mathrm{OH}=\mathrm{H}_{2} \mathrm{O}+\mathrm{O}_{2}, \mathrm{H}+\mathrm{HO}_{2}=\mathrm{H}_{2} \mathrm{O}+\mathrm{O}$ ) (Conaire et al., 2004; Mousavipour and Saheb, 2007; Burke et al., 2010, 2012; Shimizu et al., 2011), whereas for high-pressure conditions, the inclusion of reaction $\mathrm{H}+\mathrm{OH}+\mathrm{M}=\mathrm{H}_{2} \mathrm{O}+\mathrm{M}$ would be fundamental for the description of laminar flame speeds (Conaire et al., 2004; Konnov, 2008; Burke et al., 2012). Konnov

\section{REFERENCES}

Abdmouleh, Z., Alammari, R. A., and Gastli, A. (2015). Review of policies encouraging renewable energy integration \& best practices. Renew. Sustain. Energy Rev. 45, 249-262. doi: 10.1016/j.rser.2015.01.035

Anderlohr, J. M., Pires da Cruz, A., Bounaceur, R., and Battin-Leclerc, F. (2010). Thermal and kinetic impact of $\mathrm{CO}, \mathrm{CO}_{2}$, and $\mathrm{H}_{2} \mathrm{O}$ on the postoxidation of IC-engine exhaust gases. Combust. Sci. Technol. 182, 39-59. doi: 10.1080/00102200903190844

Basevich, V. Y., and Frolov, S. M. (2007). Kinetics of blue flames in the gasphase oxidation and combustion of hydrocarbons and their derivatives. Russian Chem. Rev. 76, 867-884. doi: 10.1070/RC2007v076n09ABEH 003703

Baulch, D. L., Griffiths, J. F., Pappin, A. J., and Sykes, A. F. (1988). Thirdbody interactions in the oscillatory oxidation of hydrogen in a well stirred flow reactor. J. Chem. Soc. Faraday Trans. 84, 1575-1586. doi: 10.1039/f19888 401575

Burke, M. P., Chaos, M., Dryer, F. L., and Ju, Y. (2010). Negative pressure dependence of mass burning rates of $\mathrm{H}_{2} / \mathrm{CO} / \mathrm{O}_{2} /$ diluent flames at low flame temperatures. Combust. Flame 157, 618-631. doi: 10.1016/j.combustflame.2009.08.009

Burke, M. P., Chaos, M., Ju, Y., Dryer, F. L., and Klippenstein, S. J. (2012). Comprehensive $\mathrm{H}_{2} / \mathrm{O}_{2}$ kinetic model for high-pressure combustion. Int. J. Chem. Kinet. 44, 444-474. doi: 10.1002/kin.20603

Cadman, P., Thomas, G. O., and Butler, P. (2000). The auto-ignition of propane at intermediate temperatures and high pressures. Phys. Chem. Chem. Phys. 2, 5411-5419. doi: 10.1039/b003665j

Cavaliere, A., and de Joannon, M. (2004). Mild combustion. Prog. Energy Combust. Sci. 30 329-366. doi: 10.1016/j.pecs.2004.02.003

Chen, L., and Ghoniem, A. F. (2014). Modeling CO2 chemical effects on $\mathrm{CO}$ formation in oxy-fuel diffusion flames using detailed, quasi-global, and global reaction mechanisms. Combust. Sci. Technol. 186, 829-848. doi: 10.1080/00102202.2014.883384

Colorado, A. F., Herrera, B. A., and Amell, A. A. (2010). Performance of a flameless combustion furnace using biogas and natural gas. Bioresour. Technol. 101, 2443-2449. doi: 10.1016/j.biortech.2009.11.003
(2008) also suggested the inclusion of the termolecular reaction $\mathrm{HO}_{2}+\mathrm{HO}_{2}+\mathrm{M}=\mathrm{H}_{2} \mathrm{O}_{2}+\mathrm{O}_{2}+\mathrm{M}$ for laminar flame speed prediction.

Burke et al. (2010) have recently suggested that the pressure dependence description should be described separately for different bath gases, with center broadening factors from 0.5 to 0.7 for Ar, 0.5 to 0.7 for $\mathrm{N}_{2}$, and 0.6 to 0.8 for $\mathrm{H}_{2} \mathrm{O}$. Burke et al. (2010) have also discussed the necessity to include "nonlinear mixing rules" for the reaction $\mathrm{H}+\mathrm{O}_{2}+\mathrm{M}=\mathrm{HO}_{2}+$ $\mathrm{M}$ in presence of multicomponent bath gases, in agreement with Li et al. (2004).

In this perspective, at low-intermediate temperatures and in presence of conspicuous amount of non-inert species, the chemical kinetic validation procedure suffers the lack of experimental results in simple and controlled facilities.

\section{AUTHOR CONTRIBUTIONS}

MJ and PS have synergistically contributed to the research concept and design and equally contributed to the manuscript through fruitful discussions and data analyses. The work represents a summary of their joint research activities. PS has assembled the data and written the first release of the manuscript. MJ has critically revised the paper up to the final version.

Conaire, Ó. M., Curran, H. J., Simmie, J. M., Pitz, W. J., and Westbrook, C. K. (2004). A comprehensive modeling study of hydrogen oxidation. Int. J. Chem. Kinet. 36, 603-622. doi: 10.1002/kin.20036

Cozzi, F., and Coghe, A. (2012). Effect of air staging on a coaxial swirled natural gas flame. Exp. Thermal Fluid Sci. 43, 32-39. doi: 10.1016/j.expthermflusci.2012.04.002

Dally, B. B., Riesmeier, E., and Peters, N. (2004). Effect of fuel mixture on moderate and intense low oxygen dilution combustion. Combust. Flame 137, 418-431. doi: 10.1016/j.combustflame.2004. 02.011

Davis, S. G., Joshi, A. V., Wang, H., and Egolfopoulos, F. (2005). An optimized kinetic model of $\mathrm{H}_{2} / \mathrm{CO}$ combustion. Proc. Combust. Inst. 30, 1283-1292. doi: 10.1016/j.proci.2004.08.252

de Joannon, M., Cavaliere, A., Donnarumma, R., and Ragucci, R. (2002). Dependence of autoignition delay on oxygen concentration in mild combustion of high molecular weight paraffin. Proc. Combust. Inst. 29, 1139-1146. doi: 10.1016/S1540-7489(02)80144-4

de Joannon, M., Cavaliere, A., Faravelli, T., Ranzi, E., Sabia, P., and Tregrossi, A. (2005). Analysis of process parameters for steady operations in methane mild combustion technology. Proc. Combust. Inst. 30, 2605-2612. doi: 10.1016/j.proci.2004.08.190

de Joannon, M., Sabia, P., Cozzolino, G., Sorrentino, G., and Cavaliere, A. (2012b). Pyrolitic and oxidative structures in hot oxidant diluted oxidant (HODO) MILD combustion. Combust. Sci. Technol. 184, 1207-1218. doi: 10.1080/00102202.2012.664012

de Joannon, M., Sorrentino, G., and Cavaliere, A. (2012a). MILD combustion in diffusion-controlled regimes of hot diluted fuel. Combust. Flame 159, 1832-1839. doi: 10.1016/j.combustflame.2012. 01.013

Demirbas, A. (2004). Combustion characteristics of different biomass fuels. Prog Energy Combust. Sci. 30, 219-230. doi: 10.1016/j.pecs.2003.10.004

Derudi, M., and Rota, R. (2011). Experimental study of the mild combustion of liquid hydrocarbons. Proc. Combust. Inst. 33, 3325-3332. doi: 10.1016/j.proci.2010.06.120

Donohoe, N., Heufer, K. A., Aul, C. J., Petersen, E. L., Bourque, G., Gordon, R., et al. (2015). Influence of steam dilution on the ignition of hydrogen, syngas 
and natural gas blends at elevated pressures. Combust. Flame 162, 1126-1135. doi: 10.1016/j.combustflame.2014.10.005

Dunn-Rankin, D. (Ed.). (2011). Lean Combustion: Technology and Control. San Diego, CA: Academic Press.

Evans, M. J., Chinnici, A., Medwell, P. R., and Ye, J. (2017). Ignition features of methane and ethylene fuel-blends in hot and diluted coflows. Fuel 203, 279-289. doi: 10.1016/j.fuel.2017.04.113

Faravelli, T., Frassoldati, A., and Ranzi, E. (2003). Kinetic modeling of the interactions between $\mathrm{NO}$ and hydrocarbons in the oxidation of hydrocarbons at low temperatures. Combust. Flame 132, 188-207. doi: 10.1016/S0010-2180(02)00437-6

Fedyaeva, O. N., Artamonov, D. O., and Vostrikov, A. A. (2018). Features of propene oxidation in argon, carbon dioxide and water vapor media at a high density of reagents. J. Eng. Thermophys. 27, 405-414. doi: 10.1134/S1810232818040045

Frassoldati, A., Faravelli, T., and Ranzi, E. (2003). Kinetic modeling of the interactions between $\mathrm{NO}$ and hydrocarbons at high temperature. Combust. Flame 135, 97-112. doi: 10.1016/S0010-2180(03)00152-4

Gallagher, S. M., Curran, H. J., Metcalfe, W. K., Healy, D., Simmie, J. M., and Bourque, G. (2008). A rapid compression machine study of the oxidation of propane in the Negative Temperature Coefficient regime. Combust. Flame 153, 316-333. doi: 10.1016/j.combustflame.2007.09.004

Gerasimov, G. Y., and Shatalov, O. P. (2013). Kinetic mechanism of combustion of hydrogen-oxygen mixtures. J. Eng. Phys. Thermophys. 86, 987-995. doi: 10.1007/s10891-013-0919-7

Glarborg, P., and Bentzen, L. L. (2007). Chemical effects of a high $\mathrm{CO}_{2}$ concentration in oxy-fuel combustion of methane. Energy Fuels 22, 291-296. doi: 10.1021/ef7005854

Gurentsov, E. V. E., Divakov, O. G. E., and Eremin, A. V. (2002). Ignition of multicomponent hydrocarbon/air mixtures behind shock waves. High Temp. 40, 379-386. doi: 10.1023/A:1016012007493

Hashemi, H., Christensen, J. M., Gersen, S., Levinsky, H., Klippenstein, S. J., and Glarborg, P. (2016). High-pressure oxidation of methane. Combust. Flame 172, 349-364. doi: 10.1016/j.combustflame.2016.07.016

Hashemi, H., Christensen, J. M., Harding, L. B., Klippenstein, S. J., and Glarborg, P. (2019). High-pressure oxidation of propane. Proc. Combust. Inst. 37, 461-468. doi: 10.1016/j.proci.2018.07.009

Hashemi, H., Jacobsen, J. G., Rasmussen, C. T., Christensen, J. M., Glarborg, P., Gersen, S., et al. (2017). High-pressure oxidation of ethane. Combust. Flame 182, 150-166. doi: 10.1016/j.combustflame.2017.03.028

He, Y., Zou, C., Song, Y., Luo, J., Jia, H., Chen, W., et al. (2017). Comparison of the characteristics and mechanism of $\mathrm{CO}$ formation in $\mathrm{O}_{2} / \mathrm{N}_{2}, \mathrm{O}_{2} / \mathrm{CO}_{2}$ and $\mathrm{O}_{2} / \mathrm{H}_{2} \mathrm{O}$ atmospheres. Energy 141, 1429-1438. doi: $10.1016 /$ j.energy.2017.11.043

Herzler, J., Jerig, L., and Roth, P. (2004). Shock-tube study of the ignition of propane at intermediate temperatures and high pressures. Combust. Sci. Technol. 176, 1627-1637. doi: 10.1080/00102200490 487201

Ho, R. J., Kumaran, P., and Yusoff, M. Z. (2016). "Development of high efficiency and low emission low temperature combustion diesel engine with direct egr injection", in IOP Conference Series: Earth and Environmental Science 32 012016. IOP Conference Series: Earth and Environmental Science, Volume 32, International Conference on Advances in Renewable Energy and Technologies (ICARET 2016), Putrajaya.

Hosseini, S. E., and Wahid, M. A. (2013). Biogas utilization: experimental investigation on biogas flameless combustion in lab-scale furnace. Energy Conver. Manage. 74, 426-432. doi: 10.1016/j.enconman.2013.06.026

Hosseini, S. E., and Wahid, M. A. (2016). Hydrogen production from renewable and sustainable energy resources: promising green energy carrier for clean development. Renew. Sustain. Energy Rev. 57, 850-866. doi: 10.1016/j.rser.2015.12.112

Huang, Y., and Yang, V. (2009). Dynamics and stability of lean-premixed swirl-stabilized combustion. Prog. Energy Combust. Sci. 35, 293-364. doi: $10.1016 /$ j.pecs.2009.01.002

Isaac, B. J., Parente, A., Galletti, C., Thornock, J. N., Smith, P. J., and Tognotti, L. (2013). A novel methodology for chemical time scale evaluation with detailed chemical reaction kinetics. Energy Fuels 27, 2255-2265. doi: 10.1021/ ef301961x
Jasper, A. W., Miller, J. A., and Klippenstein, S. J. (2013). Collision efficiency of water in the unimolecular reaction $\mathrm{CH}_{4}\left(+\mathrm{H}_{2} \mathrm{O}\right) \leftrightarrows \mathrm{CH}_{3}+\left(+\mathrm{H}_{2} \mathrm{O}\right)$ : Onedimensional and two-dimensional solutions of the low-pressure-limit master equation. J. Phys. Chem. A 117, 12243-12255. doi: 10.1021/jp409086w

Jasper, A. W., Oana, C. M., and Miller, J. A. (2015). "Third-body" collision efficiencies for combustion modeling: hydrocarbons in atomic and diatomic baths. Proc. Combust. Inst. 35, 197-204. doi: 10.1016/j.proci.2014. 05.105

Ju, Y., Reuter, C. B., Yehia, O. R., Farouk, T. I., and Won, S. H. (2019). Dynamics of cool flames. Prog. Energy Combust. Sci. 75:100787. doi: 10.1016/j.pecs.2019.100787

Katsuki, M., and Hasegawa, T. (1998). The science and technology of combustion in highly preheated air. Proc. Combust. Inst. 27, 3135-3146. doi: 10.1016/S0082-0784(98)80176-8

Keyhani, A., Marwali, M. N., and Dai, M. (2010). Integration of Green and Renewable Energy in Electric Power Systems, Vol. 20. Hoboken, NJ: Wiley.

Khalil, A. E. E., and Gupta, A. K. (2011). Distributed swirl combustion for gas turbine application. Appl. Energy 88, 4898-4907. doi: 10.2514/6.2011-64

Konnov, A. A. (2008). Remaining uncertainties in the kinetic mechanism of hydrogen combustion. Combust. Flame 152, 507-528. doi: 10.1016/j.combustflame.2007.10.024

Le Cong, T., and Dagaut, P. (2008). Experimental and detailed kinetic modeling of the oxidation of methane and methane/syngas mixtures and effect of carbon dioxide addition. Combust. Sci. Technol. 180, 2046-2091. doi: 10.1080/00102200802265929

Le Cong, T., and Dagaut, P. (2009a). Oxidation of $\mathrm{H}_{2} / \mathrm{CO}_{2}$ mixtures and effect of hydrogen initial concentration on the combustion of $\mathrm{CH}_{4}$ and $\mathrm{CH}_{4} / \mathrm{CO}_{2}$ mixtures: experiments and modeling. Proc. Combust. Inst. 32, 427-435. doi: 10.1016/j.proci.2008.05.079

Le Cong, T., and Dagaut, P. (2009b). Experimental and detailed modeling study of the effect of water vapor on the kinetics of combustion of hydrogen and natural gas, impact on NOx. Energy Fuels 23, 725-734. doi: 10.1021/ef800832q

Lee, M. C., Seo, S. B., Yoon, J., Kim, M., and Yoon, Y. (2012). Experimental study on the effect of $\mathrm{N}_{2}, \mathrm{CO}_{2}$, and steam dilution on the combustion performance of H2 and CO synthetic gas in an industrial gas turbine. Fuel 102, 431-438. doi: 10.1016/j.fuel.2012.05.028

Levy, Y., Sherbaum, V., and Arfi, P. (2004). Basic thermodynamics of floxcom, the low-nox gas turbines adiabatic combustor. Appl. Thermal Eng. 24, 1593-1605. doi: 10.1016/j.applthermaleng.2003.11.022

Li, J., Zhao, Z., Kazakov, A., and Dryer, F. L. (2004). An updated comprehensive kinetic model of hydrogen combustion.Int. J. Chem. Kinet. 36, 566-575. doi: 10.1002/kin.20026

Li, P., Dally, B. B., Mi, J., and Wang, F. (2013). MILD oxy-combustion of gaseous fuels in a laboratory-scale furnace. Combust. Flame 160, 933-946. doi: 10.1016/j.combustflame.2013.01.024

Li, P., Mi, J., Dally, B. B., Wang, F., Wang, L., Liu, Z., et al. (2011). Progress and recent trend in MILD combustion. Sci. China Technol. Sci. 54, 255-269. doi: 10.1007/s11431-010-4257-0

Li, P., Wang, F., Mi, J., Dally, B. B., and Mei, Z. (2014). MILD combustion under different premixing patterns and characteristics of the reaction regime. Energy Fuels 28, 2211-2226. doi: 10.1021/ef402357t

Lubrano Lavadera, M., Sabia, P., de Joannon, M., Cavaliere, A., and Ragucci, R. (2018a). Propane oxidation in a jet stirred flow reactor. the effect of $\mathrm{H}_{2} \mathrm{O}$ as diluent species. Exp. Thermal Fluid Sci. 95, 35-43. doi: 10.1016/j.expthermflusci.2018.01.008

Lubrano Lavadera, M., Song, Y., Sabia, P., Herbinet, O., Pelucchi, M., Stagni, A., et al. (2018b). Oscillatory behavior in methane combustion: influence of the operating parameters. Energy Fuels 32, 10088-10099. doi: 10.1021/acs.energyfuels.8b00967

Lubrano Lavadera, M. L., Sabia, P., Sorrentino, G., Ragucci, R., and de Joannon, M. (2016). Experimental study of the effect of $\mathrm{CO}_{2}$ on propane oxidation in a jet stirred flow reactor. Fuel 184, 876-888. doi: 10.1016/j.fuel.2016.06.046

Lückerath, R., Meier, W., and Aigner, M. (2008). FLOX ${ }^{\circledR}$ combustion at high pressure with different fuel compositions. J. Eng. Gas Turb. Power 130:011505. doi: 10.1115/1.2749280

Lund, H., and Kempton, W. (2008). Integration of renewable energy into the transport and electricity sectors through V2G. Energy Pol. 36, 3578-3587. doi: 10.1016/j.enpol.2008.06.007 
Luo,X., Wang, J., Dooner, M., and Clarke, J. (2015). Overview of current development in electrical energy storage technologies and the application potential in power system operation. Appl. Energy 137, 511-536. doi: 10.1016/j.apenergy.2014.09.081

Mardani, A., Tabejamaat, S., and Ghamari, M. (2010). Numerical study of influence of molecular diffusion in the mild combustion regime. Combust. Theory Model. 14, 747-774. doi: 10.1080/13647830.2010.512959

Mardani, A., Tabejamaat, S., and Hassanpour, S. (2013). Numerical study of $\mathrm{CO}$ and $\mathrm{CO}_{2}$ formation in $\mathrm{CH}_{4} / \mathrm{H}_{2}$ blended flame under MILD condition. Combust. Flame 160, 1636-1649. doi: 10.1016/j.combustflame.2013.04.003

McKendry, P. (2002). Energy production from biomass (part 2): conversion technologies. Bioresour. Technol. 83, 47-54. doi: 10.1016/S0960-8524(01)00119-5

Mendiara, T., and Glarborg, P. (2009). Reburn chemistry in oxy-fuel combustion of methane. Energy Fuels 23, 3565-3572. doi: 10.1021/ef9001956

Milani, A., and Wünning, J. G. (2007). Flameless oxidation technology, advanced combustion and aero thermal technologies. Environ. Protect. Pollut. Reduct. 6, 343-352. doi: 10.1007/978-1-4020-6515-6_26

Minamoto, Y., and Swaminathan, N. (2015). Subgrid scale modelling for MILD combustion. Proc. Combust. Inst. 35, 3529-3536. doi: $10.1016 /$ j.proci.2014.07.025

Minamoto, Y., Swaminathan, N., Cant, S. R., and Leung, T. (2014). Morphological and statistical features of reaction zones in MILD and premixed combustion. Combust. Flame 161, 2801-2814. doi: 10.1016/j.combustflame.2014.04.018

Mousavipour, S. H., and Saheb, V. (2007). Theoretical study on the kinetic and mechanism of $\mathrm{H}+\mathrm{HO}_{2}$ reaction. Bull. Chem. Soc. Japan 80, 1901-1913. doi: $10.1246 /$ bcsj. 80.1901

Mueller, M. A., Yetter, R. A., and Dryer, F. L. (1999). Flow reactor studies and kinetic modeling of the $\mathrm{H}_{2} / \mathrm{O}_{2} / \mathrm{NOx}$ and $\mathrm{CO} / \mathrm{H}_{2} \mathrm{O} / \mathrm{O}_{2} / \mathrm{NOx}$ reactions. Int. J. Chem. Kinet. 31, 705-724. doi: 10.1002/(SICI)10974601(1999)31:10> 705::AID-JCK4<3.0.CO;2-\#

Noor, M. M., Wandel, A. P., and Yusaf, T. (2013a). Analysis of recirculation zone and ignition position of non-premixed bluff-body for biogas mild combustion. Int. J. Automot. Mech. Eng. 8, 1176-1186. doi: 10.15282/ijame.8.2013.8.0096

Noor, M. M., Wandel, A. P., and Yusaf, T. (2013b). Design and development of mild combustion burner. J. Mech. Eng. Sci. 5, 662-676. doi: 10.15282/jmes.5.2013.13.0064

Østergaard, P. A. (2012). Comparing electricity, heat and biogas storages' impacts on renewable energy integration. Energy 37, 255-262. doi: 10.1016/j.energy.2011.11.039

Özdemir, I. B., and Peters, N. (2001). Characteristics of the reaction zone in a combustor operating at mild combustion. Exp. Fluids 30, 683-695. doi: $10.1007 /$ s003480000248

Parente, A., Galletti, C., and Tognotti, L. (2008). Effect of the combustion model and kinetic mechanism on the MILD combustion in an industrial burner fed with hydrogen enriched fuels. Int. J. Hydrog. Energy 33, 7553-7564. doi: 10.1016/j.ijhydene.2008.09.058

Parente, A., Malik, M. R., Contino, F., Cuoci, A., and Dally, B. B. (2016). Extension of the eddy dissipation concept for turbulence/chemistry interactions to MILD combustion. Fuel 163, 98-111. doi: 10.1016/j.fuel.2015.09.020

Park, J., Hwang, D. J., Choi, J. G., Lee, K. M., Keel, S. I., and Shim, S. H. (2003). Chemical effects of $\mathrm{CO}_{2}$ addition to oxidizer and fuel streams on flame structure in $\mathrm{H} 2-\mathrm{O} 2$ counterflow diffusion flames. Int. J. Energy Res. 27, 1205-1220. doi: 10.1002/er.946

Penyazkov, O. G., Ragotner, K. A., Dean, A. J., and Varatharajan, B. (2005). Autoignition of propane-air mixtures behind reflected shock waves. Proc. Combust. Inst. 30, 1941-1947. doi: 10.1016/j.proci.2004.08.122

Reddy, V. M., Katoch, A., Roberts, W. L., and Kumar, S. (2015). Experimental and numerical analysis for high intensity swirl based ultra-low emission flameless combustor operating with liquid fuels. Proc. Combust. Inst. 35, 3581-3589. doi: $10.1016 /$ j.proci.2014.05.070

Riccius, O., Smith, R., Güthe, F., and Flohr, P. (2005). “The GT24/26 combustion technology and high hydrocarbon ("c2+") fuels", in ASME Turbo Expo 2005: Power for Land, Sea, and Air; American Society of Mechanical Engineers (Reno, NV: ASME Turbo Expo), 595-602.

Sabia, P., de Joannon, M., Lubrano Lavadera, M., Giudicianni, P., and Ragucci, R. (2014). Autoignition delay times of propane mixtures under
MILD conditions at atmospheric pressure. Combust. Flame 161, 3022-3030. doi: 10.1016/j.combustflame.2014.06.006

Sabia, P., de Joannon, M., Picarelli, A., and Ragucci, R. (2013). Methane auto-ignition delay times and oxidation regimes in MILD combustion at atmospheric pressure. Combust. Flame 160, 47-55. doi: 10.1016/j.combustflame.2012.09.015

Sabia, P., Lubrano Lavadera, M., Giudicianni, P., Sorrentino, G., Ragucci, R., and de Joannon, M. (2015). CO2 and $\mathrm{H} 2 \mathrm{O}$ effect on propane auto-ignition delay times under mild combustion operative conditions. Combust. Flame 162, 533-543. doi: 10.1016/j.combustflame.2014.08.009

Sabia, P., Romeo, F., de Joannon, M., and Cavaliere, A. (2007). VOC destruction by water diluted hydrogen mild combustion. Chemosphere 68, 330-337. doi: 10.1016/j.chemosphere.2006.12.061

Saxena, S., and Bedoya, I. D. (2013). Fundamental phenomena affecting low temperature combustion and HCCI engines, high load limits and strategies for extending these limits. Prog Energy Combust. Sci. 39, 457-488. doi: 10.1016/j.pecs.2013.05.002

Shao, J., Choudhary, R., Susa, A., Davidson, D. F., and Hanson, R. K. (2019). Shock tube study of the rate constants for $\mathrm{H}+\mathrm{O} 2+\mathrm{M} \rightarrow \mathrm{HO} 2+\mathrm{M}(\mathrm{M}=\mathrm{Ar}$, $\mathrm{H} 2 \mathrm{O}, \mathrm{CO} 2, \mathrm{~N} 2)$ at elevated pressures. Proc. Combust. Inst. 37, 145-152. doi: 10.1016/j.proci.2018.05.077

Shimizu, K., Hibi, A., Koshi, M., Morii, Y., and Tsuboi, N. (2011). Updated kinetic mechanism for high-pressure hydrogen combustion. J. Propuls. Power 27, 383-395. doi: $10.2514 / 1.48553$

Sidey, J., and Mastorakos, E. (2015). Visualization of MILD combustion from jets in cross-flow. Proc. Combust. Inst. 35, 3537-3545. doi: 10.1016/j.proci.2014.07.028

Sidey, J., Mastorakos, E., and Gordon, R. L. (2014). Simulations of autoignition and laminar premixed flames in methane/air mixtures diluted with hot products. Combust. Sci. Technol. 186, 453-465. doi: 10.1080/00102202.2014.883217

Sjöberg, M., Dec, J. E., and Hwang, W. (2007). "Thermodynamic and chemical effects of EGR and its constituents on HCCI autoignition," in SAE Transactions. 271-289. doi: 10.4271/2007-01-0207

Sokolov, O. V., Parfenov, Y. V., Arutyunov, V. S., Basevich, V. V., and Vedeneev, V. L. (1996). Study of cool-dame phenomena during self-ignition of methaneoxygen mixtures. Russian Chem. Bull. 45, 2316-2320. doi: 10.1007/BF01 435374

Song, Y., Zou, C., He, Y., and Zheng, C. (2015). The chemical mechanism of the effect of $\mathrm{CO}_{2}$ on the temperature in methane oxy-fuel combustion. Int. J. Heat Mass Transf. 86, 622-628. doi: 10.1016/j.ijheatmasstransfer.2015.03.008

Sorrentino, G., Ceriello, G., De Joannon, M., Sabia, P., Ragucci, R., Van Oijen, J., et al. (2018). Numerical investigation of moderate or intense low-oxygen dilution combustion in a cyclonic burner using a flamelet-generated manifold approach. Energy Fuels 32, 10242-10255. doi: 10.1021/acs.energyfuels.8b01099

Sorrentino, G., Sabia, P., Bozza, P., Ragucci, R., and de Joannon, M. (2019). Low- $\mathrm{NO}_{\mathrm{x}}$ conversion of pure ammonia in a cyclonic burner under locally diluted and preheated conditions. Appl. Energy 254:113676. doi: 10.1016/j.apenergy.2019.113676

Spliethoff, H., Greul, U., Rüdiger, H., and Hein, K. R. (1996). Basic effects on $\mathrm{NO}_{\mathrm{x}}$ emissions in air staging and reburning at a bench-scale test facility. Fuel 75 , 560-564. doi: 10.1016/0016-2361(95)00281-2

Tsuji, H., Gupta, A., Hasegawa, T., Katsuki, M., Kishimoto, K., and Morita, M. (2003). High Temperature Air Combustion, From Energy Conservation to Pollution Reduction. Boca Raton, FL: CRC Press.

Van Oijen, J. A. (2013). Direct numerical simulation of autoigniting mixing layers in MILD combustion. Proc. Combust. Inst. 34, 1163-1171. doi: 10.1016/j.proci.2012.05.070

Van Vuuren, D. P., Stehfest, E., Gernaat, D. E., Doelman, J. C., Van den Berg, M., Harmsen, M., et al. (2017). Energy, land-use and greenhouse gas emissions trajectories under a green growth paradigm. Glob. Environ. Change 42, 237-250. doi: 10.1016/j.gloenvcha.2016.05.008

Varga, T., Nagy, T., Olm, C., Zsély, I. G., Pálvölgyi, R., Valkó, É., et al. (2015). Optimization of a hydrogen combustion mechanism using both direct and indirect measurements. Proc. Combust. Inst. 35, 589-596. doi: 10.1016/j.proci.2014.06.071

Wang, B. L., Olivier, H., and Grönig, H. (2003). Ignition of shockheated $\mathrm{H}_{2}$-air-steam mixtures. Combust. Flame 133, 93-106. doi: 10.1016/S0010-2180(02)00552-7 
Wang, L., Liu, Z., Chen, S., Zheng, C., and Li, J. (2013). Physical and chemical effects of $\mathrm{CO}_{2}$ and $\mathrm{H}_{2} \mathrm{O}$ additives on counterflow diffusion flame burning methane. Energy Fuels 27, 7602-7611. doi: 10.1021/ef401559r

Wang, Z., Herbinet, O., Hansen, N., and Battin-Leclerc, F. (2019). Exploring hydroperoxides in combustion: history, recent advances and perspectives. Prog. Energy Combust. Sci.73, 132-181. doi: 10.1016/j.pecs.2019.02.003

Weber, R., Orsino, S., Lallemant, N., and Verlaan, A. (2000). Combustion of natural gas with high temperature air and large quantities of flue gas. Proc. Combust. Inst. 28, 1315-1321. doi: 10.1016/S0082-0784(00) 80345-8

Weber, R., Smart, J. P., and vd Kamp, W. (2005). On the (MILD) combustion of gaseous, liquid, and solid fuels in high temperature preheated air. Proc. Combust. Inst. 30, 2623-2629. doi: 10.1016/j.proci.2004.08.101

Wünning, J. A., and Wünning, J. G. (1977). Flameless oxidation to reduce thermal no-formation. Prog. Energy Combust. Sci. 23, 81-94. doi: 10.1016/S0360-1285(97)00006-3

Xie, Y., Wang, J., Xu, N., Yu, S., and Huang, Z. (2014b). Comparative study on the effect of $\mathrm{CO}_{2}$ and $\mathrm{H}_{2} \mathrm{O}$ dilution on laminar burning characteristics of $\mathrm{CO} / \mathrm{H}_{2} /$ air mixtures. Int. J. Hydrog. Energy 39, 3450-3458. doi: 10.1016/j.ijhydene.2013.12.037

Xie, Y., Wang, J., Xu, N., Yu, S., Zhang, M., and Huang, Z. (2014a). Thermal and chemical effects of water addition on laminar burning velocity of syngas. Energy Fuels 28, 3391-3398. doi: 10.1021/ef4020586
Zabetta, E. C., Hupa, M., and Saviharju, K. (2005). Reducing NOx emissions using fuel staging, air staging, and selective noncatalytic reduction in synergy. Ind. Eng. Chem. Res. 44, 4552-4561. doi: 10.1021/ie050051a

Zhang, Z., Li, X., Zhang, L., Luo, C., Lu, B., Xu, Y., et al. (2019). Effect of $\mathrm{H}_{2} \mathrm{O} / \mathrm{CO}_{2}$ mixture on heat transfer characteristics of pulverized coal MILD-oxy combustion. Fuel Process. Technol. 184:27. doi: 10.1016/j.fuproc.2018.11.011

Zhukov, V. P., Sechenov, V. A., and Starikovskii, A. Y. (2005). Autoignition of a lean propane-air mixture at high pressures. Kinet Catal. 46, 319-327. doi: 10.1007/s10975-005-0079-7

Zou, C., He, Y., Song, Y., Han, Q., Liu, Y., Guo, F., et al. (2015). The characteristics and mechanism of the NO formation during oxy-steam combustion. Fuel 158, 874-883. doi: 10.1016/j.fuel.2015.06.034

Conflict of Interest: The authors declare that the research was conducted in the absence of any commercial or financial relationships that could be construed as a potential conflict of interest.

Copyright (c) 2020 Sabia and de Joannon. This is an open-access article distributed under the terms of the Creative Commons Attribution License (CC BY). The use, distribution or reproduction in other forums is permitted, provided the original author(s) and the copyright owner(s) are credited and that the original publication in this journal is cited, in accordance with accepted academic practice. No use, distribution or reproduction is permitted which does not comply with these terms. 